\title{
15. ANALYSIS OF CONGLOMERATES AND ASSOCIATED SEDIMENTARY ROCKS OF THE DAITO RIDGE, DEEP SEA DRILLING PROJECT SITE 445
}

\author{
William Mills, Scripps Institution of Oceanography, La Jolla, California
}

\begin{abstract}
The geological history of the Daito Ridge is revealed in the clasts of proximal channel conglomerates recovered at DSDP Site 445. The clasts are the product of a middle Eocene transgression of the Daito Ridge. The major clasts, in order of abundance, are volcanic rocks, middle-Eocene bioclasts, and Cretaceous reef limestones.

Pebbles of basalt within the Cretaceous reef limestones help confirm the late-Mesozoic origin of the Daito Ridge. From the lack of Paleocene shallow-water fossils, it is believed that the Daito Ridge remained in deep water after the Late Cretaceous global sea-level rise until the middle Eocene. During the middle Eocene, the bioclasts were derived from contemporaneous carbonate deposition upon the ridge and reworked along with the volcanic rocks and some Cretaceous limestones to make up the conglomerates that were recovered at Site 445. Post-depositional zeolitization of the conglomerates indicates thermal activity on the ridge at least through the middle Eocene.

Evidence supporting the island-arc origin of the ridge consists in detritial minerals derived from blueschist and greenschist metamorphic facies. These minerals are found in the matrix of the conglomerate and associated sedimentary rocks.
\end{abstract}

\section{INTRODUCTION}

Conglomerates recovered from DSDP Hole 445 during Leg 58 contain clasts which originated from volcanic rocks and reefs that once capped the Daito Ridge during the Late Cretaceous to middle Eocene.

Hole 445 is in a small, east-west-trending depression on the east end of the Daito Ridge. This ridge, a part of the Daito Ridge and Basin province, is located in the northwest Philippine Sea. Two other ridges (Amami Plateau and the Oki-Daito Ridge) are also within this province, which is bounded on the northwest by the Ryuku Trench, on the northeast by the Kyushu-Palau Ridge, and on the south by the West Philippine Basin (Figures 1 and 2).

The ridges of this province are interpreted as remnant island arcs. Geophysical studies of Murauchi (1968) and Karig $(1972,1975)$ have shown that in crustal structure and curved configuration the ridges are similar to island arcs. Further evidence comes from rocks dredged from the ridge (Mizuno et al., 1977), which are typical of island arcs: granodiorite, andesite, dacite tuffs, serpentinite, and greenschist metamorphic rocks.

It was hoped that drilling at Site $\mathbf{4 4 5}$ would increase understanding of the relationship between these rocks and the subsidence history of the area. However, because of bad weather, drilling was terminated before the basement complex was reached. Although many questions remain unanswered, a great deal of information was gained about the paleoenvironment of the Daito Ridge from the Late Cretaceous to the late Quaternary.

\section{GENERAL PETROGRAPHY}

The middle-Eocene conglomerates (age based on nannoplankton) occur in Cores 445-69 through 445-94, an interval of 237 meters. There are 13 major conglomerate beds (0.5-5.0 m thick) and numerous smaller beds (less than $0.5 \mathrm{~m}$ ). Volcanic material dominates as clasts in all the conglomerate beds, with varying amounts of reefal limestones and shallow-water bioclasts (Plate 1, Figures 1-3). The angularity and poor sorting of the clasts indicate a nearby source. The topography of the ridge limits the source area to either the north or central peaks surrounding the depression, or both (Figure 2).

The conglomerates are overlain by 655 meters of calcareous oozes and chalks with graded cycles. In the lower portion of this section, chert and radiolarite occur. Sedimentary rocks associated with conglomerates are dominated by greenish-gray mudstone and sandy mudstone, along with some graded and massive sandstones. (See Site 445 report, this volume, for a summary of lithologies).

The mudstone and sandy mudstone contain abundant terrigenous material and are occasionally calcareous (enriched in calcareous nannofossils). The most common sedimentary structures are thin laminae of silt and silty sand. The graded and massive sandstones are essentially fine-grained equivalents of the conglomerates, with abundant volcanic (hyaloclastic?) and shallow-water carbonate debris (Plate 2, Figure 1). The only significant difference is the presence of detrital mineral grains in the sandstones, which are not found as mineral 


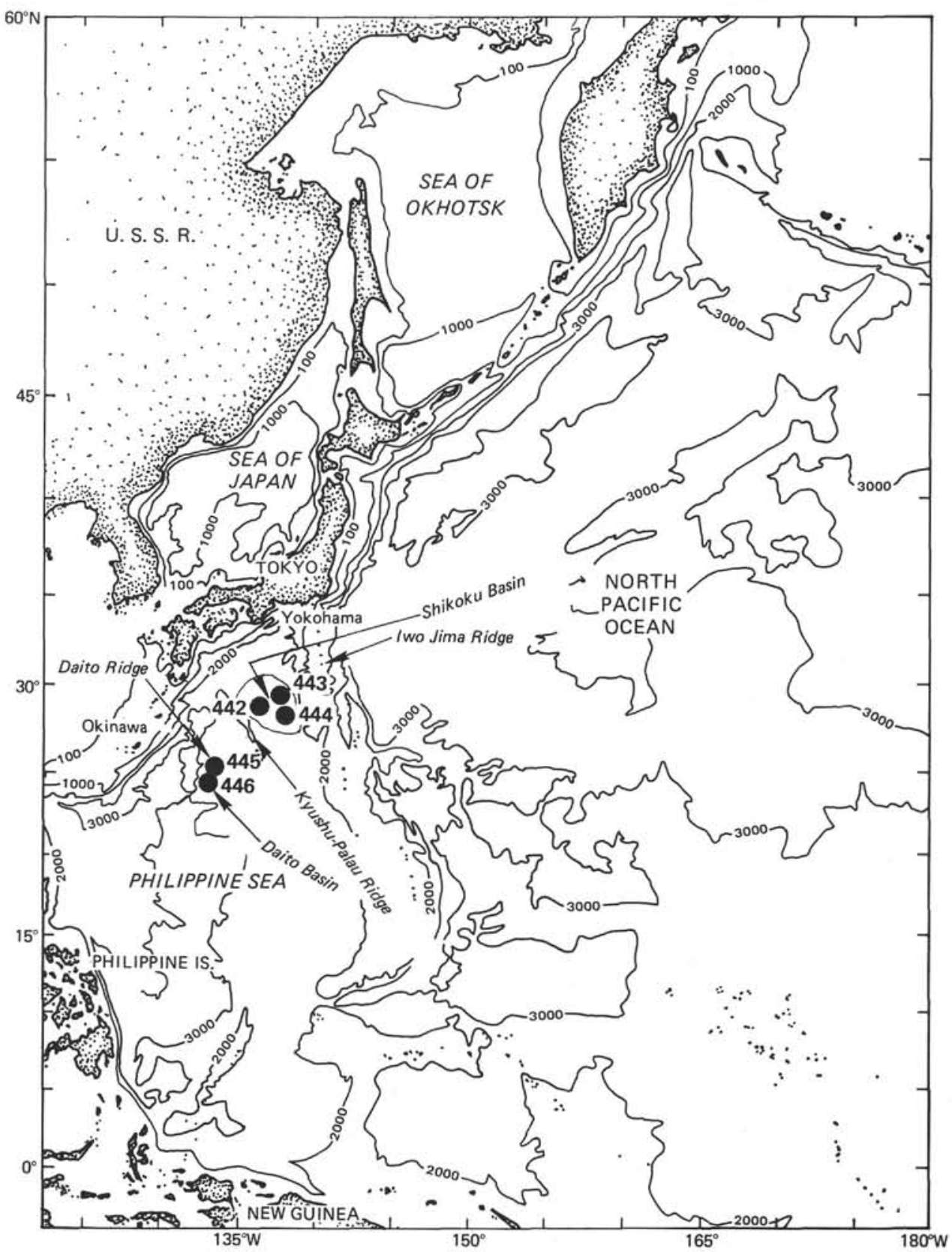

Figure 1. Location of DSDP Site 445.

constituents of the conglomerate clasts. These are hornblende ( $X$, yellow green; $Y$, olive green; $Z$, dark green; extinction angles $\left.19-26^{\circ}\right)$, metamorphic hornblende $(X$, yellow; $Y$, brown; $Z$, dark red; extinction angles less than $9^{\circ}$ ), epidote, quartz, and albite. These minerals are probably associated with the low-pressure metamorphic rocks on the ridge (Yuasa and Watanabe, 1977).

\section{CLAST LITHOLOGY}

For convenience of description and interpretation, the clasts are divided into three groups based on their origin: extrusive volcanic, reefal (L. Cretaceous), and shallow-water carbonate (m. Eocene).

\section{Volcanic Rocks}

Alkali Basalt, Gabbro, and Andesite

This is by far the largest category. These rocks occur in all conglomerate beds, and often make up more than 90 per cent of the total clast population. They range in shape from sub-rounded to angular, and in size from a coarse sand to boulders greater than $15 \mathrm{~cm}$ (Plate 1, Figures 2,3).

Being the largest category, it is also one of the most difficult to describe. The difficulties arise from the different mineral assemblages expressed in a variety of volcanic textures, and compounded by the intense alteration, often rendering textures and minerals vague clay- 


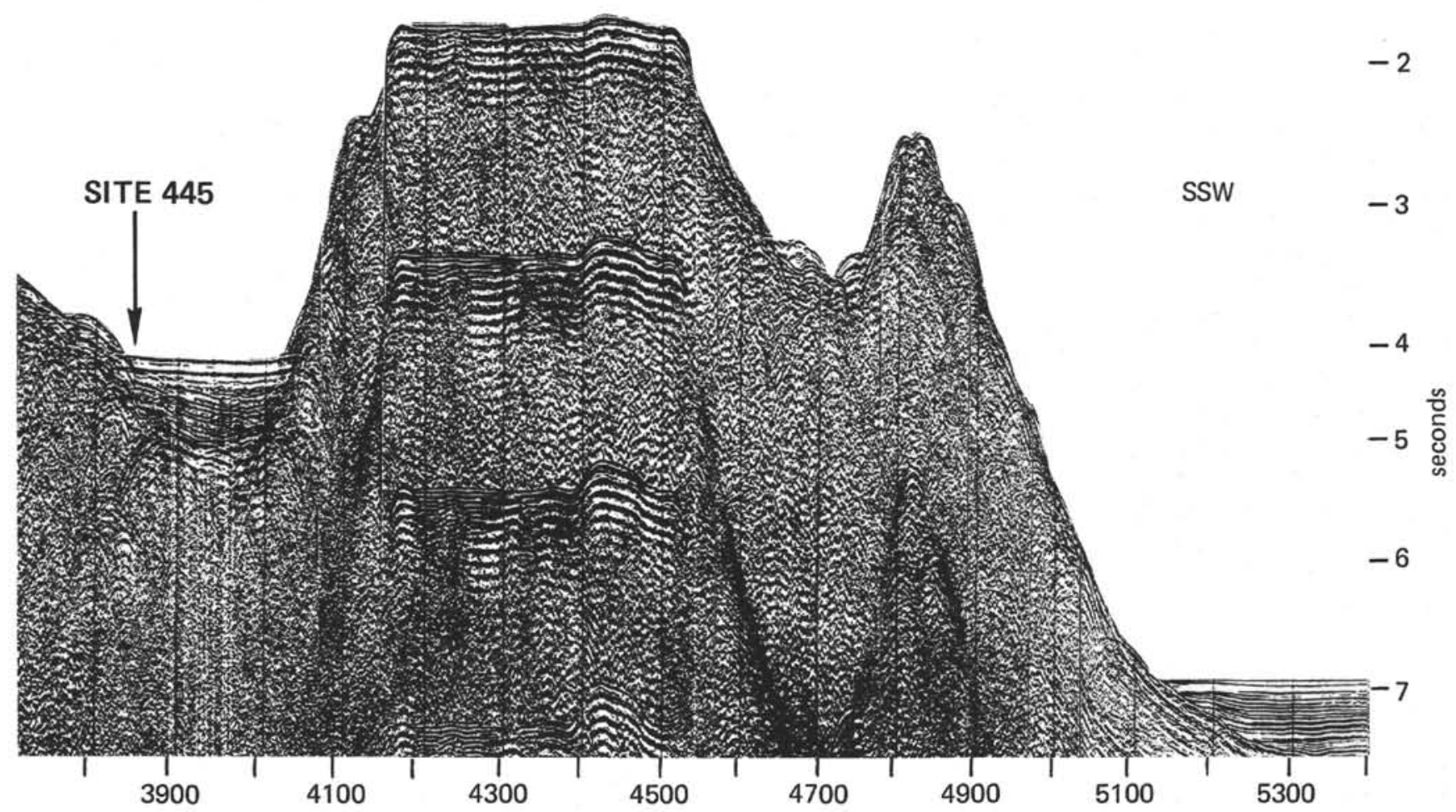

Figure 2. Seismic-reflection profile through Daito Ridge by $R / V$ Kaiyo-Maru.

ey ghosts. Therefore, instead of describing a number of different specimens individually, a general description of the volcanic rocks as a whole is provided.

The volcanic rocks are dominantly phyric and intersertal, although observed textures range from a rare, medium-grained holocrystalline texture to the more common glassy, undercooled textures (indicative of submarine extrusion). In undercooled textures, plagioclase occurs either in bow-tie spherulites or skeletal morphologies, whereas in intersertal textures, plagioclase phenocrysts more commonly occur as synneusis clusters. While the plagioclase microlites are usually unoriented, they sometimes have parallel orientation (presumably aligned with the direction of flow), producing a trachytic texture.

Scoriaceous and amygdaloidal basalts are also common. Vesicles of the amygdaloidal basalts range from 0.5 to $4.0 \mathrm{~mm}$ and are mineralized by stilbite and calcite. Cataclastic textures are also observed in a few clasts. These clasts appear to have been basalt originally. Plagioclase is the only recognizable mineral, although it is intensely fractured and sheared. Serpentine minerals commonly have grown along shear planes and in some cases the clasts were entirely serpentinized.

The majority of the volcanic rocks belong to the alkaline-basalt group (Plate 2, Figure 2). Identification is based solely on modal mineralogy of the basalt, and agrees with geochemical data obtained by Nisterenko (this volume). Using the Michel-Levy method, I found that plagioclase phenocrysts have an An range of 20 to 40 per cent, that is, within the oligoclase-andesine range. Plagioclase occurs both as phenocrysts and as microlites. Usually, the large phenocrysts are partially resorbed. Clinopyroxene is identified as augite; the titaniferous variety was not seen in the basalt clasts, but was occasionally seen in the conglomerate matrix as a detrital mineral. The clinopyroxene usually occurs as a groundmass phase, but occasionally as phenocrysts. Olivine usually occurs as phenocrysts, but was also observed in the groundmass. The olivine, where not altered to antigorite (Plate 2, Figure 3 ) or iddingsite, appears to be zoned. Olivine and clinopyroxene are present in about 30 to 40 per cent of the basalts; the majority are plagiolase-phyric. The dominant opaque mineral is titanomagnetite, but pyrite and pictolite are also common. Leucite was the only noted feldspathoid, and it was found in only one clast. The leucite occurred as a small, euhedral phenocryst.

Other observed volcanic rocks are a clast of mediumgrained gabbro and several clasts of highly altered quartz andesites. The gabbro mineralogy is 50 per cent labradorite (An 58-64\%), 30 per cent olivine, 15 per cent clinopyroxene, and 5 per cent pictolite. The quartz andesite mineralogy is roughly 65 per cent plagioclase, 10 per cent quartz, 15 per cent altered hypersthene, 5 per cent altered clinopyroxene, and 5 per cent pyrite. The quartz is partially resorbed, and the two pyroxene phases are partially altered to chlorite.

Alkali basalts are usually associated with oceanic-island type volcanism; occurrence with other island-arc lithologies (Mizuno et al.,1977) is anomalous. The occurrence of gabbro is best explained as a xenolith; xenoliths are common in alkali basalts. The andesites are typical of island-arc rocks. 


\section{Hydrothermal Minerals}

Clasts composed of minerals of hydrothermal origin are common in all the conglomerate beds, sometimes making up as much as 5 per cent of the clasts. They appear as tabular clasts from 0.5 to $1.0 \mathrm{~cm}$ in length, with alternating reddish-orange and yellowish-white bands. $\mathrm{X}$-ray diffraction identifies the reddish-orange material as hematite and the yellowish-white material as stilbite and laumontite, with occasional heulandite and calcite.

In thin section, some of the clasts show symmetrical increase of crystal size toward the center. This type of crystal growth, along with the mineralogy and tabular shape of the clasts, is the basis for concluding that these clasts originated from veins deposited from late-stage hydrothermal fluids of the associated volcanic activity. Further evidence supporting the volcanic association is the highly altered volcanic rock which is part of some of these clasts.

\section{Hyaloclastic Sandstones}

Clasts of hyaloclastic sandstone (Plate 2, Figure 4) occur in all the conglomerate units, but never make up more than a small percentage of the total clasts. The size of these clasts is 0.4 to $5.0 \mathrm{~cm}$, and they are sub-rounded. These rocks are composed of very angular, somewhat blocky fragments of vesicular basalt, basaltic glass, sideromelane, and plagioclase; that range from fine to coarse sand. The degree of alteration varies from fairly fresh volcanic grains with minor alteration along grain boundaries to very extensive alteration where the grains are rimmed by highly birefringent green smectites and often partially replaced by zeolites. The basaltic glass is usually altered to palagonite. Commonly these hignly altered clasts are veined discordantly and cemented with sparry calcite and zeolites (stilbite?).

The hyaloclastic-sandstone clasts lack sorting and noticeable structures; therefore, they are not considered to be reworked. The alteration of these clasts suggests intense heat, contact with sea water, and possibly contact with the degassing fluids of the associated volcanic flow. Carlisle (1963) described how hyaloclastic breccias build upon the advancing submarine volcanic flow and are often overridden and buried. It is reasonable to assume that the same situation occurred here, thus producing the type of alteration and cementation of the hyaloclastite seen here.

\section{Cretaceous Reef Limestones}

Clasts representing several reefal facies (lagoon, back reef, and reef channel or slope deposits) were recovered in the conglomerate beds of Cores 445-84 to 445-94. These clasts are sub-rounded to angular and range in size from 2 to $20 \mathrm{~cm}$. These limestones have an age range of Barremian to Maestrichtian, based on the presence of Orbitolina, a large ( $4 \mathrm{~mm}$ or more) benthic, back-reef foraminifer (Plate 3, Figure 1). These clasts were derived from reefs which are fairly typical of the reefs that flourished in the west Pacific during the Cretaceous. For a detailed description of the reefal clasts, see Plate 3.
Apparently, this is the first reported occurrence of Cretaceous reef limestones in the Daito Ridge and Basin province. The occurrence of extraclasts of basalt (Plate 3 , Figures 3 and 4 ) within the reef channel or foreslope limestones is especially fortuitous. (Basalt extraclasts are similar to the basalts described in the section of the paper dealing with volcanic rocks). These basaltic extraclasts allow bracketing of the minimum age for the beginning of basaltic volcanic activity on the Daito Ridge at 65 to $118 \mathrm{~m} . y$. Perhaps identification of the Orbitolina species could narrow this minimum-age bracket, which is used for dating the limestones. It should be made clear that the suggestion is not being made that the other basalt clasts are limited to a Cretaceous age. $\mathrm{An}{ }^{40} \mathrm{Ar}-{ }^{39} \mathrm{Ar}$ date published by Ozima et al. (this volume) dates a basalt clast as Paleocene. Therefore, it would not be unreasonable to assume that the basaltic volcanic activity began in the Cretaceous and continued through, perhaps, the early Eocene.

These Cretaceous reefal clasts are significant in other ways, too. First, they show that the Daito Ridge from the Cretaceous to the middle Eocene was near the equator. Second, they show that sufficient volcanic activity had taken place on the Daito Ridge to raise it to a level to allow for the development of reefs. Third, the lack of shallow water fossils, from the end of the Cretaceous until the middle Eocene, correlates with the transgression of Pacific reefs at the end of the Cretaceous (only reworked Paleocene planktonic foraminifers from the Oki-Daito Ridge were found at DSDP Site 294,Leg 31). Finally, the occurrence of Cretaceous rocks supports Karig's (1973) estimate that the Daito Ridge and Basin province is possibly of late-Mesozoic age (based on basin-depth and heat-flow similarities to the Mesozoic Pacific crust).

\section{Middle-Eocene Shallow-Water Bioclasts}

The most-numerous fossils present in the conglomerate are the large, benthic, shallow water foraminifer Nummulites boninensis (occasionally as large as $4.5 \mathrm{~cm}$ in cross section). Often these large foraminifers are encrusted by the red alga Archeolithothamium. Other benthic foraminifers, red algae, and mollusk shells were also recovered (Plate 4). There are no corals or any other evidence to suggest that reefs were developed on the Daito Ridge during the Eocene. Most likely, the carbonate buildup was a boundstone constructed by foraminifers and algae. This agrees with the finding of the Nummulites-bearing limestone dredged by GDP-15 Cruise in 1976.

By or before the middle Eocene, the Daito Ridge had emerged above sea level as a result of Paleocene volcanic and tectonic activity, lowering of sea level, or, most likely, a combination of both. It appears that subsidence began quickly (geologically speaking) after the emergence of the ridge, perhaps caused by the cessation of volcanic activity and resulting isostatic sinking due to thermal contraction of the crust (Mizuno et al.,1978). It was during this middle-Eocene transgression that all the described clasts were eroded and deposited as conglomerate beds. It is believed that during and shortly after 
this transgression an environment was provided suitable to allow shallow water flora and fauna to flourish. Paleomagnetism studies (Kinoshita, this volume; Site 445 report, this volume) and the presence of middle-Eocene shallow-water fossils indicate that the Daito Ridge still remained in equatorial waters.

\section{DEPOSITIONAL PROCESSES}

Resedimentation is the major depositional process responsible for the sedimentary rocks at Site 445. Many of the typical methods for studying resedimented sedimentary rocks cannot be used, because the cores are disoriented. However, different styles of deposition for the three major lithologies (conglomerates, sandstones, and mudstones) were distinguished.

For the conglomerates, three depositional styles can be distinguished: (1) turbidity currents, (2) debris flow, and (3) massive slumping.

Turbidite deposition (Plate 1, Figure 1) accounts for many of the minor conglomerate beds. These beds represent the coarser portion of a Bouma sequence $\left(\mathrm{T}_{\mathrm{a}}\right)$. They are characterized by good grading and stratification. Commonly, bioclasts are concentrated in the upper parts of these sequences. The matrix is commonly clay-free, with high porosity.

Debris-flow deposits account for the greater portion of the conglomerates (Plate 1, Figure 2). This depositional style is recognized by the chaotic orientation of the clasts, poor sorting, lack of stratification, and grading. But, unless eroded, the upper 5 to $10 \mathrm{~cm}$ of the debris-flow deposits are stratified and often show good grading. This probably results from a turbidity current subsequently generated by the debris flow (Hampton, 1972). The debris-flow deposits also have a much higher clay/clast ratio than deposits of the other two styles and the clasts commonly are supported in an open framework. This high clay percentage is one of the moreimportant criteria for distinguishing debris-flow and turbidity-current deposits. In debris flows, the high ratio of clay to clast is needed to increase the density and sheer strength to provide the necessary support for the larger clasts.

Massive slumping (Plate 1, Figure 3 ) is observed in Cores 445-91 to 445-94. The conglomerates are intermixed with very coarse sandstone, as the result of the slumping. The boundaries between conglomerates and sandstones are vague at best, since the matrix of the conglomerate is identical to the sandstone. It is my belief that the alternating conglomerate and sandstone intervals are the result of slump folding and represent a single depositional event. As with the debris-flow deposits, both the sandstone and conglomerate lack stratification and grading and are poorly sorted. However, unlike the debris-flow deposits, the clay-to-clast ratio is much lower. (Much of the clay in the matrix comes from in situ weathering of the volcanic clasts and grains.)

All styles of deposition for the conglomerates are interpreted to represent proximal "turbidite" channel deposits. Excludng the sandstones associated with the conglomerates, the sandstones commonly constitute the basal section of thin turbidite cycles on the order of 2 to
5 centimeters thick. These sandstones, along with the mudstones, are interpreted as "turbidity" channel levee deposits. The sandstones also occur as thick $(0.5-1.0 \mathrm{~m})$ channel deposits. They are poorly sorted and massive, and sometimes contain small (3-10 mm) mudstone ripup clasts.

The mudstones and sandy mudstones commonly contain thin laminae of silt and silty sand (Plate 1, Figure 1, bottom). The laminations are usually inclined at angles of 5 to $10^{\circ}$. Small rotational faults and slump folds are common. Although there are diverse opinions concerning the origin of laminated mudstones, the high sedimentation rate (Site 445 report, this volume) and association with proximal "turbidite" channel conglomerates and sandstones support the interpretation that these laminated mudstones are "turbidity" channel levee deposits.

In general, the conglomerates and associated sedimentary rocks (sandstones and mudstones) are the result of proximal channel deposits (conglomerates and sandstones), the mudstones having been deposited adjacent to the channel, forming the levee. The interbedding of these lithologies is the result of meandering of the whole depositional system.

\section{CONGLOMERATE MATRIX AND POST- DEPOSITIONAL ZEOLITIZATION}

Description of the matrix is complicated somewhat by the varied nature of the original matrix and by postdepositional zeolitization. The matrix generally consists of a mixture of clay, coarse- to fine-grained lithic sand (essentially a fine-grained equivalent of the conglomerate clasts), planktonic foraminifers, radiolarians, calcareous nannoplankton, and highly weathered silt-sized debris of volcanic-rock mineral fragments, palagonite, and amorphous iron hydroxides. In the conglomerate beds of Cores 445-74, 445-77, and 445-78, silt-sized detritial glaucophane was observed (Figure 3). Because glaucophane is a mineral of high-pressure and low-temperature metamorphism, its presence further confirms the island-arc origin of the Daito Ridge.

Identification of the clays by X-ray diffraction was only marginally successful. Contamination by the alteration products of volcanic clasts obscured the diffraction pattern, making precise identification difficult. Essentially, the clays are either from the montmorillonite group or glauconite. The montmorillonite clays predominate in the conglomerates of Cores $445-80$ to $445-90$, which commonly contain abundant microspar (recrystallized calcareous nannoplankton?). In places the microspar makes up a higher percentage of the matrix than the clays. From Core 445-79 to Core 445-69, glauconite becomes progressively predominant over the montmorillonite clays. The glauconite occurs either as internal molds of planktonic foraminifers or as spherical aggregates.

Zeolitization appears to involve only the matrix of the conglomerates, and not the associated mudstone or sandstone. Where clasts are densely packed in conglomerates, zeolitization is also absent. It appears that porosity controlled zeolitization. 


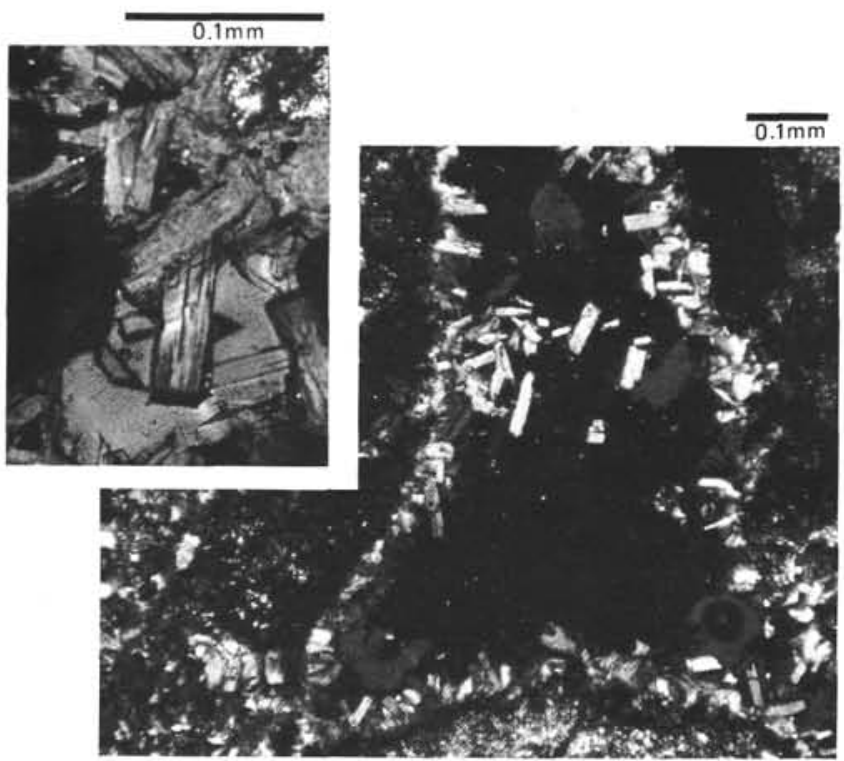

Figure 3. Photomicrograph, 445-74-3, $95 \mathrm{~cm}$. The large photo (crossed nicols) shows laumontite rimming clasts; the dark material between is glaucophane. The smaller photo (plane light) is a closeup of the laumontite crystals.

Zeolitization involved much of the original matrix being either removed or replaced by a mineral assemblage of laumontite-calcite-heulandite. Laumontite is the most abundant zeolite, usually encrusting the clasts and growing outward into the matrix (Figure 3). The interstices, where not filled with the original matrix, usually contain sparry calcite, and in places heulandite.

The effects of zeolitization on the clasts are uncertain. Many of the volcanic clasts show replacement of their original minerals by zeolites and calcite, but this alteration is just as likely the result of sea-water or deuteric alteration during volcanic eruption.

Many consider the occurrence of laumontite as the beginning of the zeolite facies of metamorphism (Hay, 1966). This is thought to involve pressures of 2.5 to 3.5 kilobars and temperatues of 300 to $350^{\circ} \mathrm{C}$. However, the shallow burial ( $3300 \mathrm{~m}$ water and $625 \mathrm{~m}$ of overlying sediment) of these rocks precludes these conditions. Also, since the zeolitization appears to be controlled by porosity, it likely is the result either of invading hydrothermal fluids or of mobilization of pore fluids within the conglomerates related to a high thermal gradient from continuing volcanic activity. Supporting the interpretation that the Daito Ridge was still thermally active through the middle Eocene is the veining of clasts and matrix in the conglomerate of Section 445-93-2 by stilbite and calcite (Plate 1, Figure 3), although there was no observed connection between these veined zeolites and the zeolites of the matrix.

\section{SUMMARY}

The conglomerates and massive sandstones represent proximal channel deposits, resulting from three deposi- tional styles: (1) debris flows, (2) turbidites, and (3) massive slumping. Interbedded with conglomerates are "turbidity" channel levee deposits of fine sandstones and mudstones.

The three major categories of clasts are volcanic rocks, Cretaceous reef limestones, and middle-Eocene bioclasts. The volcanic rocks are dominated by alkali basalts, with minor andesite and gabbro. Also associated with the volcanic rocks are hydrothermal-vein fragments and hyaloclastic-sandstone clasts.

The Cretaceous reef limestones are subdivided by environments: lagoonal, back-reef, and reef-channel or foreslope. Limestones of the latter environment contain basalt pebbles that give a minimum age range for basaltic volcanic activity on the ridge (Barremian to Maestrichtian) and support Karig's Late Mesozoic age estimates for the origin of the Daito Ridge and Basin province. The limestone clasts also show that sufficient volcanic and tectonic activity was sufficient to raise the ridge to sea level to allow for the development of reefs, before their drowning during the Late Cretaceous global sea-level rise.

The middle-Eocene bioclasts are composed mostly of the large benthic foraminifer Nummulities and encrusting red algae. Their presence indicates that the Daito Ridge emerged once again before subsidence to its present depth, marked by the change from terrigenous to pelagic sedimentation during the middle Eocene.

\section{ACKNOWLEDGMENTS}

I give my sincere thanks to Dr. Stan White for his guidance and the opportunity to write this report; to Dr. Isabella Premoli-Silva for her help on benthic-foraminifer identification; and to many others who gave me advice and support.

\section{REFERENCES}

Carlisle, D., 1963, Pillow breccias and their aquagene tuffs in Quadra Island British Columbia. J. Geol., 71, 48-71.

Hampton, M. A., 1972. The role of subaqueous debris flow in generating turbidity currents. J. Sediment Petrol., 42, 775793.

Hay, R. L., 1966. Zeolities and zeolitic reactions in sedimentary rocks. Geol. Soc. Am. Spec. Paper, 85.

Karig, D. E., 1972. Remnant arcs. Geol. Soc. Am. Bull., 83, 1057-1068.

1973. Basin genesis in the Philippine Sea. Init. Repts. DSDP, 31: Washington (U. S. Govt. Printing Office), pp. 857-879.

Mizuno, A., Okuda, Y., Nagumo, S., Kagami, H., Nasu, N., 1977. Subsidence of the Daito Ridge and associated basins, North Phillipine Sea. AAPG Memoir, 29.

Murauchi, S., Den, N., Asano, S., Hotta, H., Yoshii, T., Hagiwara, K., Ichikawa, K., Sato, T., Ludwig, W. J., Ewing, J. I., Edgar, N. T. and Houtz, R. E., 1968. Crustal structure of the Philippine Sea. J. Geophys. Res., 73, 3142-3171. 

PLATE 1

Middle-Eocene Conglomerate

Figure 1 Core photograph, 445-71-1, 50-120 cm. MiddleEocene conglomerate deposited by turbidity current $(78-95 \mathrm{~cm})$. Clasts consist of Nummulites boninensis, other benthic foraminifers and alkalibasalt fragments. From 95 to $120 \mathrm{~cm}$, the core contains laminated silty mudstone.

Figure 2 Core photograph, 445-74-3, 35-95 cm. MiddleEocene conglomerate deposited by debris flow. Note the lack of sorting and grading. The matrix of this conglomerate is glauconite with zeolite cement. The clasts are Nummulities boninensis (N) (the larger foraminifers are usually encrusted with algae), algal fragments (A), basalt pebbles (B), and mudstone rip-up clasts (MR).

Figure 3 Core photograph, 445-93-1, -2, -3, and -4. MiddleEocene conglomerates and sandstones deposited by massive slumping. Note the intermixing of conglomerate clasts with the sandstone. Clasts are dominantly basalt; middle-Eocene bioclasts are rare to absent. The Cretaceous reef-limestone clasts occur in Section 1, between 90 and $150 \mathrm{~cm}$. In Section 2 between 120 and $135 \mathrm{~cm}$, the conglomerate clasts and matrix are veined by stilbite and calcite. Evidence of post-depositional hydrothermal activity. 
PLATE 1
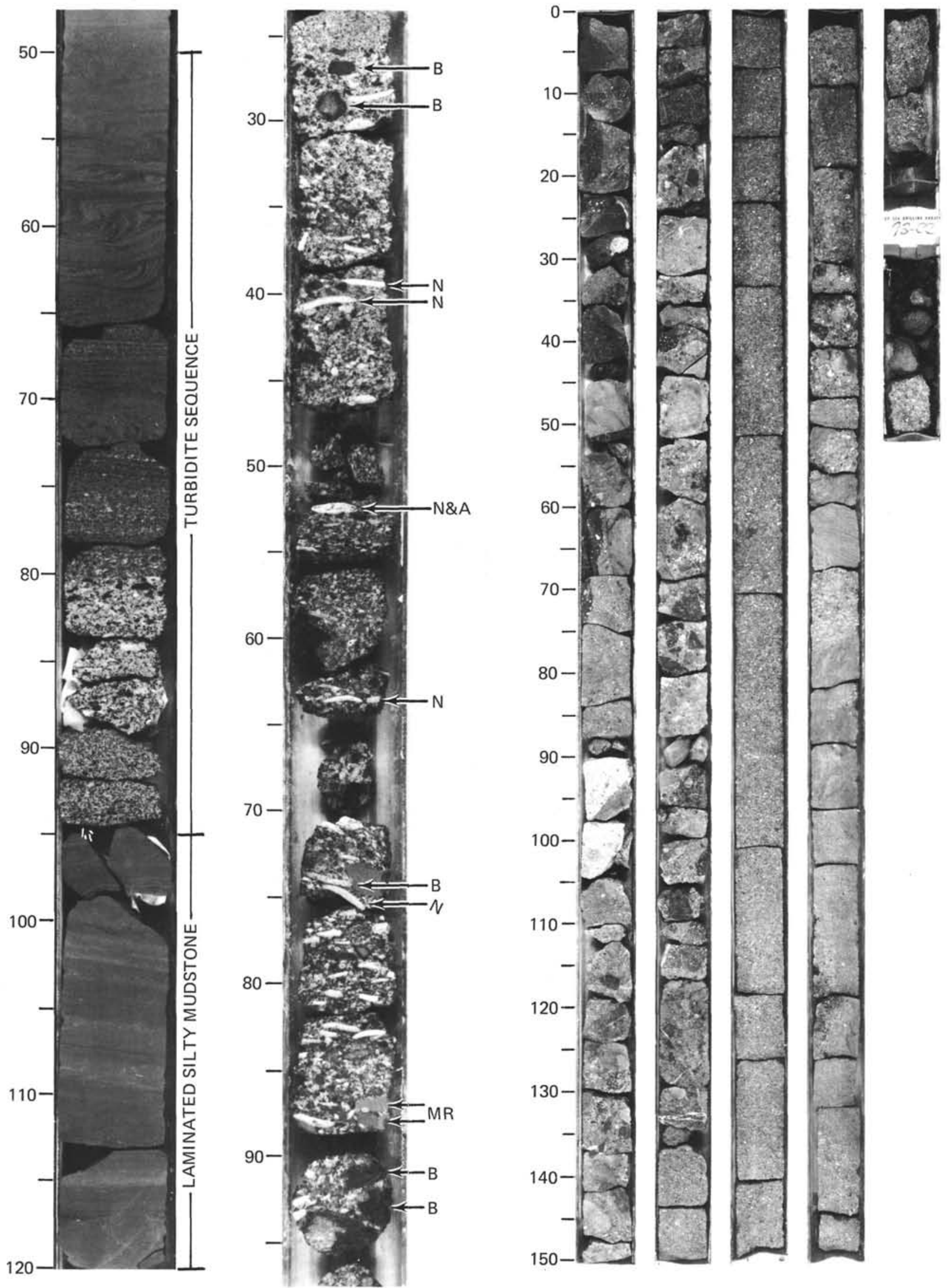


\section{PLATE 2}

Figure 1

Photomicrograph, plain light, $445-75-6,100 \mathrm{~cm}$. Middle-Eocene fossiliferous volcanic sandstones, typical of the massive, poorly sorted sandstones interbedded with the conglomerates: $(\mathrm{Al})$ red algae, $(\mathrm{Ba})$ basalt, (Hnb) hornblende, (Ml) mollusk shell, $(\mathrm{Pf})$ planktonic foraminifer, $(\mathrm{Pg})$ plagonite, and (Pl) plagioclase.

Figure 2 Photomicrograph, crossed nicols, 445-89-1, 80 $\mathrm{cm}$. Several clasts of plagioclase-phyric alkali basalt. The lighter-colored material surrounding the darker basalt clasts is sparry-calcite cement.

Figure 3 Photomicrograph, crossed nicols, 445-74-3, 63 $\mathrm{cm}$. Plagioclase-olivine-phyric basalt. Phenocryst is olivine (altered to antigorite) in a plagioclasemicrolitic groundmass.

Figure 4 Photomicrograph, crossed nicols, 445-92-3, $5 \mathrm{~cm}$. Hyaloclastic sandstone. Volcanic grains are rimmed by smectite and cemented by zeolite. 
PLATE 2
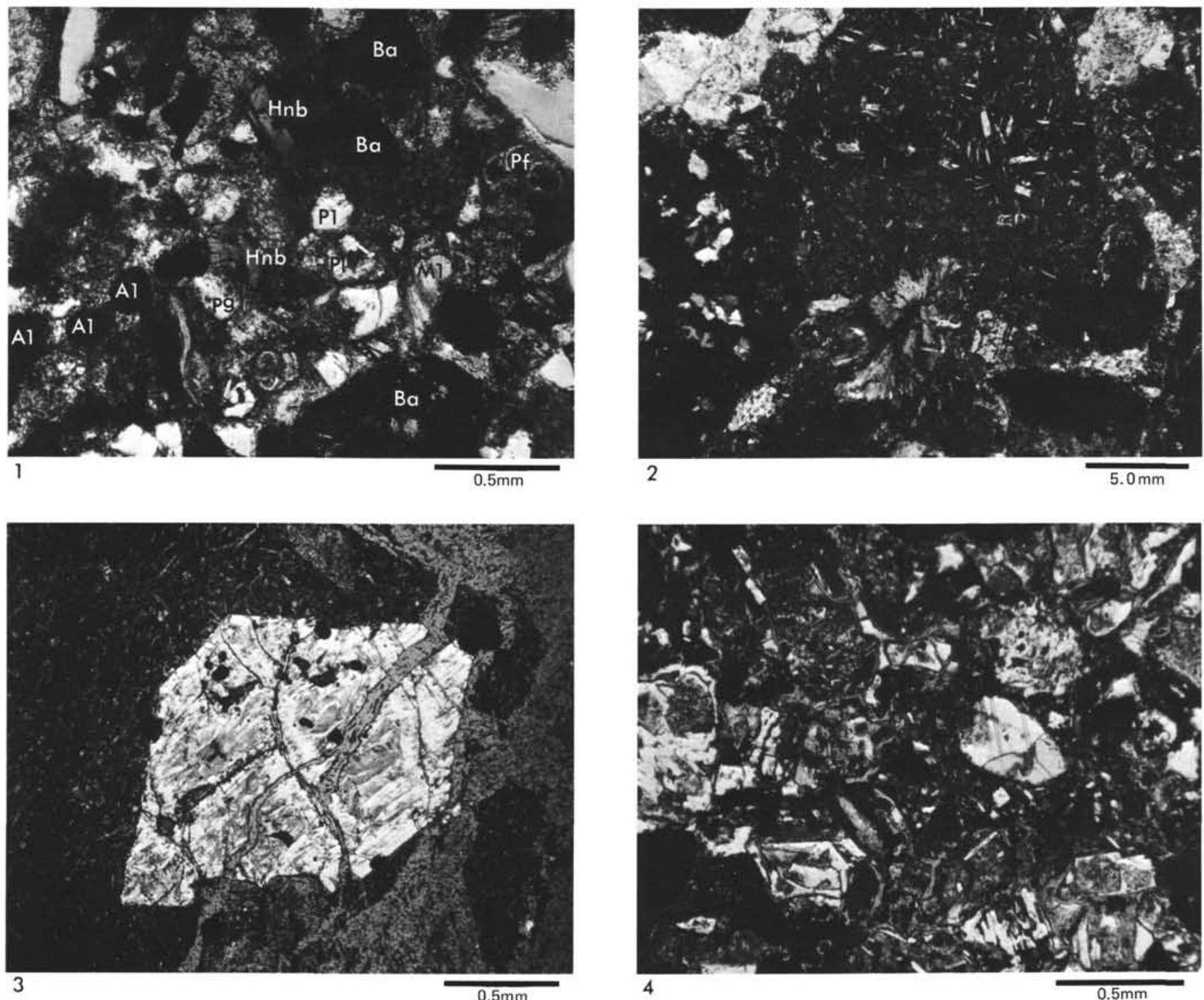


\section{PLATE 3}

Cretaceous Reef-Limestone Clasts

Key to abundance: $(\mathrm{A})=$ Abundant $(25-75 \%) ;(\mathrm{C})=$ Common $(5-24 \%) ;(R)=$ Rare $(1-4 \%)$

Figure 1 Photomicrograph, plane light. Orbitolina d'Orbigny, 1850 (Barremian to Maestrichtian), a benthic back-reef foraminifer.

Figure 2 Photomicrograph, plane light, 445-92-1, $95 \mathrm{~cm}$. Spicular pelmicrite (lagoonal). Relative abundance of components is: pellets (A), sponge spicules (calcified) (C), echinoid plates and spines (R), and miliolids (R).

Figure 3 Photomicrograph, plane light, 445-91-5, $100 \mathrm{~cm}$. Miliolid biosparite (back reef). Relative abundance of components is: miliolids (A), algae (Dasycladaceae and Corallinaceae) (C), orbitolids (R), other benthic foraminifers $(R)$, echinoid plates and spines (R), and basalt and volcanic mineral fragments $(\mathrm{R})$.

Figure 4 Photograph of Cretaceous limestone clasts (lithic extrasparite; reef channel or forereef slope), and microphotograph of the same, 445-93-1, 90-95 $\mathrm{cm}$. Relative abundance of components is: orbitolids (A), algae (Dasycladaceae and Corallinaceae) (A), basalt and volcanic mineral fragments (C), echinoid plates and spines (C), mollusk-shell fragments (C), and oolites and fragments of oosparite (R). 
PLATE 3
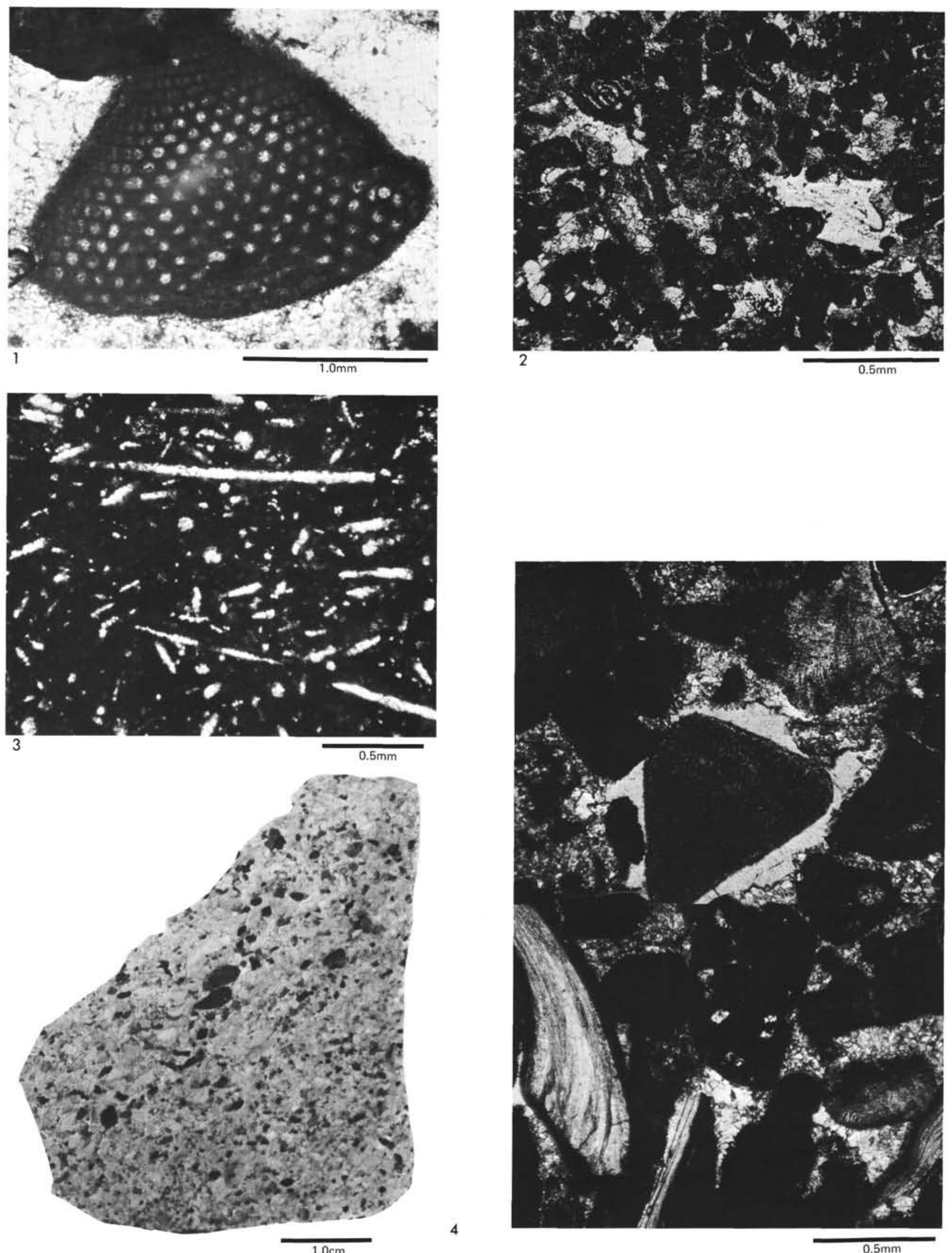
PLATE 4

Middle-Eocene Bioclasts

Figure 1 Photograph of thin section using an enlarger (negative image), 445-71-1, $80 \mathrm{~cm}$. Nummulities boninenesis, a benthic foraminifer.

Figure 2 Photomicrograph (plane light), 445-77-2, $49 \mathrm{~cm}$. Asterocyclina sp. cf. A. penuria, a benthic foraminifer.

Figure 3 Photomicrograph (crossed nicols), 445-69-33, 88 $\mathrm{cm}$. Archaeolithothamium, encrusting red alga. Other encrusting red algae, not shown here, are Lithothamium, Lithoporella, and Corallina. 
PLATE 4
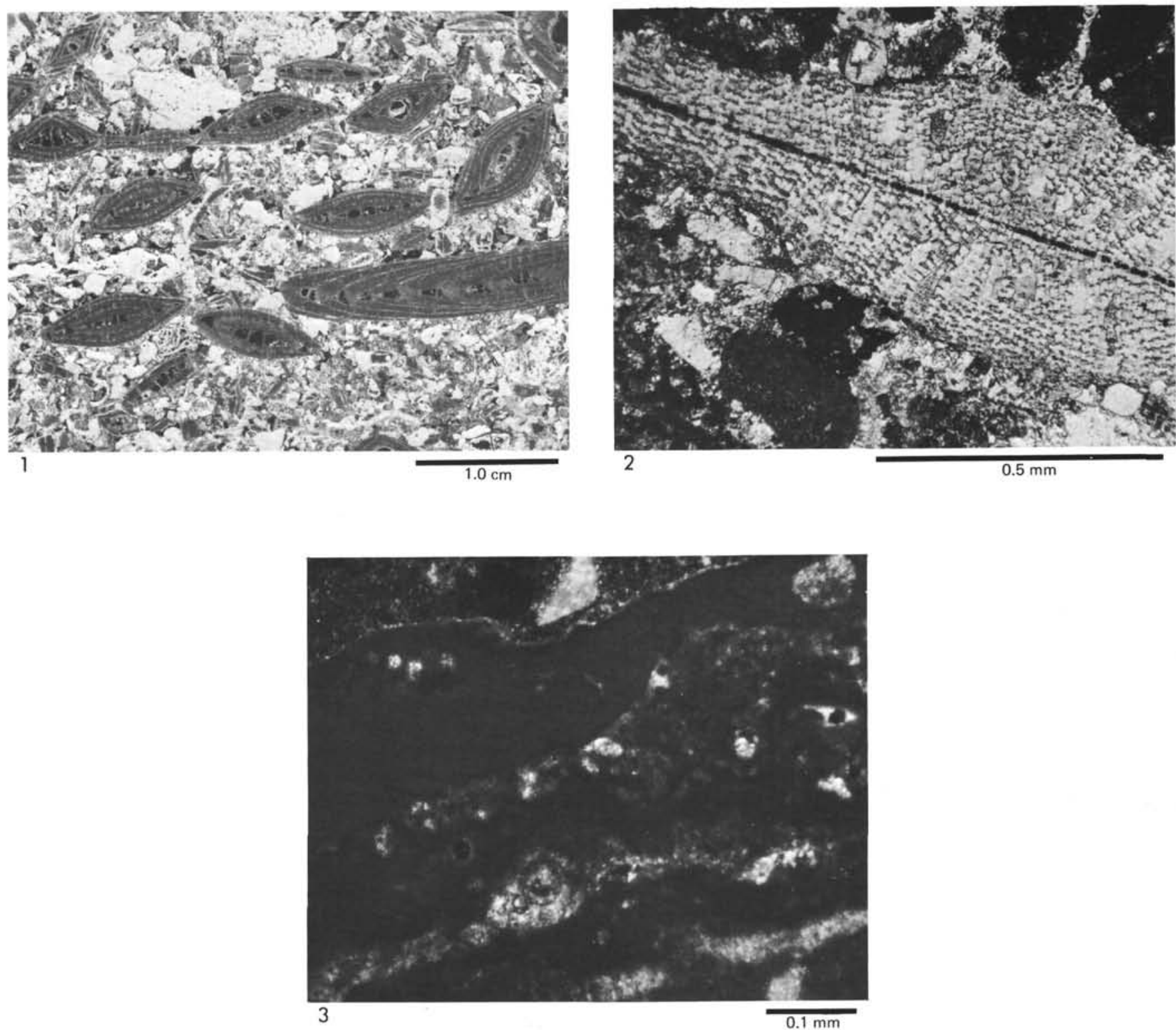